\title{
EVALUATION OF COMBINED PHARMACOLOGIC TREATMENT INVOLVING TADALAFIL AND ALPROSTADIL INTRAURETHRAL GEL FOR PENILE REHABILITATION AFTER RADICAL PROSTATECTOMY
}

\author{
CATALIN BELINSKI ${ }^{1}$, ALEXANDRU AUNGURENCI ${ }^{1 *}$, ANDREI RADULESCU ${ }^{1}$, OVIDIU \\ BRATU $^{2}$, DAN MISCHIANU ${ }^{2}$ \\ 1 "Professor Dr. D. Gerota” Urology Department, Emergency Hospital, Bucharest, Romania \\ 2 "Carol Davila” University of Medicine and Pharmacy, "Dr. Carol Davila” Central Military Emergency University \\ Hospital, Bucharest, Romania
}

*corresponding author: aungurenci1900@yahoo.com

Manuscript received: December 2020

\begin{abstract}
Radical prostatectomy is considered the safest oncological treatment for localized prostate cancer. But although the surgical technique has been improved in the last four decades the main postoperative complications for patients who undergo this operation are erectile dysfunction and urinary incontinence. The objective of the study was to compare the effect of tadalafil $5 \mathrm{mg}$ once a day as monotherapy to tadalafil $5 \mathrm{mg}$ once a day associated with alprostadil gel on-demand as postoperative penile rehabilitation in patients that underwent open or laparoscopic radical prostatectomy. It was conducted an open-label prospective nonrandomized interventional study in which we have enrolled a total number of 111 patients diagnosed with prostate cancer that underwent radical prostatectomy. Nerve sparring technique was performed selectively according to oncological indication. For the assessment of the sexual status of prostate cancer patients, we used the SHIM questionnaire both before and after surgery: immediately after urethral catheter removal, at 3 and 6 months postoperative. Based on the postoperative results of SHIM score and the treatment option for erectile dysfunction we have classified our patients in two groups: tadalafil $5 \mathrm{mg}$ group $(\mathrm{n}=56)$ and tadalafil $5 \mathrm{mg}$ associated with alprostadil gel $(\mathrm{n}=55)$. The study demonstrated the efficacy and safety of PDE5i and PGE1 combined therapy effects compared to PDE5i monotherapy for the treatment of postoperative erectile disfunction. In this regard, we can affirm that the association of Tadalafil $5 \mathrm{mg}$ once a day and Alprostadil gel on-demand can increase by 10 folds the chance of erectile function recovery after prostatectomy. Also, the combined effect of PDE5i and PGE1 could be enhanced if the laparoscopic approach is preferred over the open approach and nerve bundle preservation is performed at least unilateral.
\end{abstract}

\section{Rezumat}

Prostatectomia radicală este considerată cea mai sigură metodă terapeutică din punct de vedere oncologic pentru cancerul de prostată localizat. Deși tehnica operatorie a fost îmbunătățită de-a lungul ultimelor patru decenii, principalele complicații postoperatorii pentru pacienții care suferă această operație sunt disfuncția erectilă (DE) și incontinența urinară. Studiul desfăşurat a avut ca obiectiv compararea efectului monoterapiei cu tadalafil $5 \mathrm{mg}$ o dată pe zi, cu asocierea terapeutică a tadalafil 5 mg o dată pe zi cu alprostadil gel la cerere în cadrul reabilitării peniene postoperatorii, la pacienții care au suferit prostatectomie radicală deschisă sau laparoscopică. S-a efectuat un studiu prospectiv, open-label, nerandomizat, în care au fost incluşi un număr de 111 pacienţi diagnosticaţi cu cancer de prostată la care s-a practicat prostatectomia radicală ca tratament curativ. Tehnica de nerve sparring a fost efectuată selectiv conform indicațiilor oncologice. Pentru evaluarea statusului sexual al pacienților cu cancer de prostată, am utilizat chestionarul SHIM atât înainte cât și după operație: imediat după îndepărtarea sondei uretro-vezicale, apoi la 3 și 6 luni postoperator. Pe baza rezultatelor postoperatorii ale scorului SHIM și a opțiunii terapeutice pentru disfuncția erectilă, am putut clasifica pacienții în două grupuri: tadalafil $5 \mathrm{mg}(\mathrm{n}=56)$ și tadalafil $5 \mathrm{mg}+$ alprostadil gel $(\mathrm{n}=55)$. Prin studiul desfășurat $\mathrm{s}$-a putut demonstra eficacitatea și siguranța efectelor terapiei combinate cu PDE5i și PGE1, comparativ cu monoterapia cu PDE5i pentru tratamentul disfuncției erectile postoperatorii. În acest sens, putem afirma că asocierea tadalafil $5 \mathrm{mg}$ odată pe zi cu alprostadil gel la cerere poate crește de 10 ori șansa recuperării funcției erectile după prostatectomia radicală. De asemenea, efectul combinat al PDE5i și PGE1 ar putea fi îmbunătățit dacă se preferă abordarea laparoscopică a prostatectomiei față de abordarea deschisă, iar păstrarea bandeletelor neuro-vasculare se efectuează cel puțin unilateral.

Keywords: postprostatectomy erectile dysfunction, PDE5i/PGE1 combined therapy, penile rehabilitation

\section{Introduction}

Prostate cancer $(\mathrm{PCa})$ represents approximately $7.1 \%$ of all cancers, which makes it the second most diagnosed malignancy in men after pulmonary cancer. Though the average age of detection is 66 years the incidence and mortality of PCa are correlated with older age [1]. There is no single definitive treatment for this malignancy, but there are a variety of therapeutic 
means that can apply to different stages and risk groups (the multimodal treatment). Nowadays radical prostatectomy is considered the safest oncological treatment for localized prostate cancer, but the main postoperative complications in patients who undergo this intervention are erectile dysfunction (ED) and urinary incontinence [2,3].

In the past four decades, major improvements in radical prostatectomy were possible due to comprehensive studies of prostate neuroanatomy. Thus, in 1982 Walsh and Donker described the nerve-sparing technique which preserves the nerve bundles situated on the posterolateral sides of the prostate [3, 4]. Although this technique was initially described for open radical retropubic prostatectomy (RRP) it was easily adapted for conventional laparoscopic and robot-assisted laparoscopic prostatectomy (LARP and RALP). Despite that, ED is still subsequent in $70.4 \%$ of the cases that underwent RALP and $74.7 \%$ of the RRP patients [2]. Taking into account that the majority of patients who benefit from surgical treatment are young or middleaged, it is likely to conclude that ED may produce long-term functional and psychological impairment $[3,5,6]$.

In this regard, most patients that undergo nervesparing radical prostatectomy must follow postoperative penile rehabilitation ( $\mathrm{PRh}$ ) which includes any mean (drug or device) that can improve or restore the normal erectile function. The centrepiece of PRh is the medical treatment represented by oral medication (phosphodiesterase-5 inhibitors - PDE5i) and locally injected or applied agents (prostaglandin E1 - PGE1). Other means include vacuum devices, penile vibratory stimulation or in extremis penile implants reserved for the cases were other therapeutic measures were unsatisfactory [3, 5-9]. Even though several studies researched the impact of various oral treatments based on PDE5i alone or combined with other drugs or devices,

until now there is no consensus regarding a specific therapeutic protocol [7].

The objective of the study was to compare the effect of tadalafil $5 \mathrm{mg}$ once a day (QD) as monotherapy compared to tadalafil $5 \mathrm{mg}$ QD associated with alprostadil gel intraurethral on-demand (OD), as postoperative $\mathrm{PRh}$ in patients that underwent radical prostatectomy by either techniques (open or conventional laparoscopy). OD use of alprostadil means locally applied $10 \mathrm{~min}$ before the intercourse.

\section{Materials and Methods}

\section{Materials}

It was performed an open-label, prospective, nonrandomized, interventional study between December 2015 and January 2020 in which we have enrolled a total number of 111 patients diagnosed with PCa that later underwent surgery. Patients were evaluated and staged using d'Amico risk group, based on the PSA values, MRI results, and Gleason score obtained by prostate biopsy.

All patients were surgically treated out of which 52 patients $(46.8 \%)$ had undergone open radical retropubic prostatectomy (RRP) while the rest of 59 patients $(53.2 \%)$ were operated by conventional laparoscopy (LARP) (Table I). The surgical approach and nervesparing (NS) decisions were chosen according to each patient's risk group respecting the oncological safety surgical margins. Regarding nerve bundle preservation, it was performed in 80 patients $(72.1 \%)$ while for the rest of 31 patients $(27.9 \%)$ the prostatectomy was carried out without NS. Bilateral NS (biNS) was performed in 30 patients $(27.9 \%)$ while for the rest of $50(45 \%)$ the nerve bundles were only unilaterally preserved (uniNS). All types of nerve bundle preservation procedures were attempted during surgery, respecting the basic principles of NS technique and using as much as possible cautery free dissection and haemostasis [8].

Table I

Characteristics of each patient group by surgical technique

\begin{tabular}{|c|c|c|c|}
\hline Parameter & Open radical retropubic prostatectomy $(\mathrm{n}=52)$ & Laparoscopic surgical approach $(\mathrm{n}=59)$ & $\mathrm{p}$ Value \\
\hline Age & $68[65.4 ; 69.6]$ & $64[61.2 ; 66.8]$ & $<\mathbf{0 . 0 0 1}$ \\
\hline Local tumour stage & & & $<\mathbf{0 . 0 0 1}$ \\
\hline T2a & $2(3.8 \%)$ & $13(22 \%)$ & - \\
\hline T2b & $8(15.4 \%)$ & $23(39 \%)$ & - \\
\hline T2c & $42(80.8 \%)$ & $23(39 \%)$ & - \\
\hline Risk group & & & $12(20.3 \%)$ \\
\hline Low & $2(3.8 \%)$ & $24(40.7 \%)$ & - \\
\hline Medium & $8(15.4 \%)$ & $23(39 \%)$ & - \\
\hline High & $42(80.8 \%)$ & & - \\
\hline Type of technique & $23(44.2 \%)$ & $8(13.6 \%)$ & $<\mathbf{0 . 0 0 1}$ \\
\hline no NS & $22(42.3 \%)$ & $28(47.5 \%)$ & - \\
\hline unilateralNS & $7(13.5 \%)$ & $23(39 \%)$ & - \\
\hline bilateralNS & $8[7 ; 8]$ & $7[7 ; 8]$ & - \\
\hline Gleason Score & $3(5.8 \%)$ & $12(20.3 \%)$ & $<\mathbf{0 . 0 0 1}$ \\
\hline 6 & $22(42.3 \%)$ & $39(66.1 \%)$ & - \\
\hline 7 & $27(51.9 \%)$ & $8(13.6 \%)$ & - \\
\hline 8 & & & - \\
\hline
\end{tabular}


FARMACIA, 2021, Vol. 69, 3

\begin{tabular}{|c|c|c|c|}
\hline \hline Parameter & Open radical retropubic prostatectomy $(\mathrm{n}=52)$ & Laparoscopic surgical approach $(\mathrm{n}=59)$ & $\mathrm{p}$ Value \\
\hline Mean preoperatory PSA & $15.3[12.04 ; 19.87]$ & $8.9[7.02 ; 11.57]$ & $<\mathbf{0 . 0 0 1}$ \\
\hline Preoperatory sum & $16[14 ; 18]$ & $19[17 ; 21]$ & $<\mathbf{0 . 0 0 1}$ \\
\hline Hypertension & $36(69.2 \%)$ & $38(64.4 \%)$ & 0.59 \\
\hline Diabetes & $21(40.4 \%)$ & $7(11.9 \%)$ & $<\mathbf{0 . 0 0 1}$ \\
\hline Atherosclerosis & $27(51.9 \%)$ & $21(35.6 \%)$ & 0.083 \\
\hline Depression & $3(5.8 \%)$ & $5(8.5 \%)$ & 0.582 \\
\hline Obesity & $19(36.5 \%)$ & $20(33.9 \%)$ & 0.771 \\
\hline Smoking & $26(50 \%)$ & $19(32.2 \%)$ & 0.056 \\
\hline Alcohol & $23(44.2 \%)$ & $11(18.6 \%)$ & $\mathbf{0 . 0 0 3}$ \\
\hline Stroke & $16(30.8 \%)$ & $3(5.1 \%)$ & $<\mathbf{0 . 0 0 1}$ \\
\hline Medical treatment & & & 0.069 \\
\hline Tadalafil & $31(59.6 \%)$ & $25(42.4 \%)$ & - \\
\hline Tadalafil + alprostadil gel & $21(42.4 \%)$ & $34(57.6 \%)$ & - \\
\hline Good couple & $39(75 \%)$ & $53(89.8 \%)$ & $\mathbf{0 . 0 3 8}$ \\
\hline Postoperatory sum & $8[7 ; 12]$ & $11[9 ; 14]$ & $<\mathbf{0 . 0 0 1}$ \\
\hline Mean PSA after surgery & $0.006[0.003 ; 0.01]$ & $0.003[0.002 ; 0.005]$ & $\mathbf{0 . 0 0 6}$ \\
\hline Sum at 3 Month & $9[8 ; 14]$ & $15[10.2 ; 18]$ & $<\mathbf{0 . 0 0 1}$ \\
\hline PSA at 3 Month & $0.006[0.003 ; 0.019]$ & $0.003[0.002 ; 0.006]$ & $<\mathbf{0 . 0 0 1}$ \\
\hline Sum at 6 Month & $8.5[7 ; 14]$ & $16[10 ; 18]$ & $<\mathbf{0 . 0 0 1}$ \\
\hline PSA at 6 Month & $0.006[0.003 ; 0.026]$ & $0.003[0.002 ; 0.006]$ & $\mathbf{0 . 0 0 7}$ \\
\hline Same ED stage & $7(13.5 \%)$ & $30(50.8 \%)$ & $<\mathbf{0 . 0 0 1}$ \\
\hline
\end{tabular}

When analysing Table I we can detect a bias of selection in the group of patients that underwent laparoscopic prostatectomy. The patients with laparoscopic approach were younger, with a lower local tumour stage, a lower mean Gleason score, lower incidence of Diabetes mellitus, lower alcohol consumption, and no incidence of ischemic stroke. This bias of selection has no statistical significance when analysed using the multivariable logistic regression.

For assessment of the sexual status of PCa patients, we used the SHIM questionnaire (Sexual Health Inventory for Men) both before and after surgery. The SHIM questionnaire, also known as IIEF-5, is the short version of the IIEF-15 questionnaire (International Index of Erectile Function) is known as a fast-track inexpensive and sensitive means of investigating the presence and severity of ED. It is composed of 5 questions, each one being attributed with a 5 point scale ranging from the lowest point of sexual function $(0$ or $1-$ for the first question) to normal (5). The questions include (1) confidence in getting and keeping an erection, (2) how often erections were hard enough for penetration, (3) how often an erection could be maintained after penetration, (4) how difficult it was to maintain an erection after penetration, and (5) how often intercourse was "satisfactory". The SHIM score is the sum of each question's points attributed by the patient and it can vary between 1 and 25 points. According to this score ED can be classified as: severe (between 1 and 7 points), moderate (between 8 and 11 points), mildmoderate (12 - 16 points), mild (17 - 21 points) and no ED (22 - 25 points). The usefulness of SHIM questionnaire resides in the fact that it covers the most important aspects of the participant's erectile function which makes it an ideal tool for postoperative ED assessment [10].
For this study we have conducted three postoperative SHIM assessments: immediately after surgery, at 3 months and 6 months postoperative. We used this data to make a comparison between the preoperative and the first postoperative score to see the degree of postoperative ED. Two treatment options were recommended to our patients: tadalafil $5 \mathrm{mg}$ (QD) and tadalafil $5 \mathrm{mg}$ (QD) associated with alprostadil gel (OD). We randomized the patients in order of their presentation, the ratio was 1:1 (first patient received tadalafil QD, the second one tadalafil QD + alprostadil OD, the third tadalafil QD and further on).

All the study participants sign an informed consent for the inclusion in the study. The study was conducted in accordance with the Declaration of Helsinki, and the protocol was approved by the Institutional Ethics Committee.

Statistical analysis

Data obtained in the subsequent six months of treatment were statistically analysed using SPSS V25 program (IBM SPSS, Chicago IL, USA) and Analyze-it V5.4 (Analyze-it Software, Leeds, UK). The unevenly distributed data were presented as median and the differences in quantitative parameters were tested using nonparametric tests. Differences between semiquantitative variables were evaluated by the MannWhitney U test. The qualitative data were compared with the chi-square or Fisher exact test. The risk factors for the primary and secondary parameters (favourable evolution at 6 months) were analysed by logistic regression models, the results being expressed as a ratio of quotas (OR), and $95 \%$ confidence intervals. If the p-value of the predictor candidate in the univariate analysis was below 0.05 , this predictor was included in the multivariable logistic regression model. 


\section{Results and Discussion}

Patient distribution was well balanced between the two groups, taking into account the age, type of surgery performed, and preoperative erectile function. Tadalafil QD group included 56 patients diagnosed with $\mathrm{PCa}$ with a mean age of 66 years, the same mean age as the total patient group. Meanwhile, the combined therapy group (tadalafil + alprostadil) included 55 patients with a mean age of 65 years. In general, the distribution age ranged from 51 to 75 years old.

Most patients had comorbidities, the vast majority of them having more than one at the moment of surgery and only 4 patients had no comorbidities. In the general distribution, the most encountered side diagnosis was hypertension $(66.7 \%)$, followed by atherosclerosis $(43.2 \%)$, obesity $(35.1 \%)$, and diabetes mellitus $(25.2 \%)$. For the two analysed groups the distribution was grossly the same as in general with the remark that in the combined therapy group (tadalafil + alprostadil) the percentage of patients with atherosclerosis and obesity was significantly lower than in tadalafil group (32.7\% vs. $53.6 \%$ and $23.6 \%$ vs. $46.4 \%$ for atherosclerosis and obesity respectively). It is worth to be mentioned that cardiovascular diseases, which include hypertension, atherosclerosis, and stroke, are strongly considered as predictive factors for ED. The impact on erectile function is caused by structural and functional alterations in the penile arteries as a result of high blood pressure levels, endothelial dysfunction, but also as an effect of vasoactive circulating substances like angiotensin II [912]. It is important to take into account the impact of cardiovascular drugs which have an additional effect to erectile dysfunction. The negative effect of $\beta$-blockers, diuretics and cardiac glycosides (like digoxin) on erectile function is well known, while calcium channel blockers, $\alpha$-blockers, angiotensinconverting enzyme inhibitors, angiotensin II receptor blockers, and statins may have no impact or, by contrary, have a positive effect over EF [12-14].

ED is encountered in $51.3 \%$ of diabetes mellitus patients due to vascular and neurological damages produced by constant hyperglycaemia, but also an impaired production of $\mathrm{NO}$ and vascular endothelial growth factor. In particular, type 2 diabetes mellitus is strongly associated with obesity due to insulin resistance and an increase of adipose tissue which produces an alteration of testosterone metabolism that is another cause for ED [11, 15, 16].

Depressive disorders as well as their specific treatments are also linked to ED having a behavioural and biological modification pattern that acts in conjunction. It's estimated that the risk of ED is $39 \%$ higher in depressive patients and it has an increasing effect on the other ED factors, thus creating a vicious circle $[17,19] .7 .2 \%$ of our patients had confirmed depressive disorders at the moment of surgical intervention.
Smoking and alcohol consumption were the main habits encountered in our general group of patients: $40.5 \%$ were smokers and $30.5 \%$ of them were consuming alcohol in various amounts. Comparing our two groups we observed that higher percentages of smoking and alcohol consumption habits were found in the tadalafil group thus impacting the later postoperative recovery. The long-term effect of smoking over erectile function is caused by the vascular, neurological, and local impairments of the cavernosal tissue $[11,18]$. Small doses of alcohol consumption have been considered a protective factor for erectile function, but chronic consumption of high doses of alcohol is a determinant factor for ED due to polyneuropathy which also affects the pudendal nerves and a steady decrease of testosterone levels $[11,20]$.

The diagnosis of PCa was made according to the EAU (European Association of Urology) recommendations and the patients were categorized using the d'Amico risk group criteria: PSA value, Gleason score, and clinical stage. (Table I) Thus more than half of our patients $(58.6 \%)$ were included in the high-risk group while $28.8 \%$ and $12.6 \%$ were categorized as medium risk respectively low-risk patients. The repartition of the risk category respected the same line in our two treatment groups.

Regarding the surgical method, the percentages of laparoscopic approaches were higher in Tadalafil + Alprostadil group (61.8\% vs. $44.6 \%)$ compared to the tadalafil group. By contrast, for RRP the predominance was in the tadalafil group (55.4\% vs. $38.2 \%)$. Nerve bundle preservation was performed as often as possible, respecting the indications of tumour stage and risk group classification. In both groups, the highest percentage of patients had undergone uniNS $(44.6 \%$ respectively $45.5 \%$ ), unlike biNS were the higher percentages of patients were in the tadalafil + alprostadil group (36.4\%) compared to the other one. Particularly the tadalafil group had the highest percentage of non NS patients (37.5\%), compared to the combined treatment group.

The preoperative EF assessment gave us some valuable information that we used to compare with postoperative and post-treatment results. Thus the mean preoperative SHIM score was 18 in general distribution which was the same as for the tadalafil + alprostadil group, while for the tadalafil group the mean preoperative SHIM score was 17. Correlated with the SHIM scale we could observe that more than half of the patients $(55.9 \%, \mathrm{n}=62)$ had mild $\mathrm{ED}, 32 \%$ of them had mild-moderate ED $(n=36), 2.7 \%$ had moderate ED $(n=3)$, while $9 \%$ had no $\operatorname{ED}(n=10)$ and no patient had severe ED preoperatively. In the treatment groups, the distribution was grossly the same as in the general one with the difference that the tadalafil + alprostadil group had a higher percentage of patients with mild ED (67.27\%) and no moderate or severe ED patients. Another parameter that we 
have taken into account was the concept of a good couple that we've defined as the patient's perception and satisfaction about the sexual life of the couple. Out of the 111 patients included in our study $82.9 \%$ $(n=92)$ positively responded to this concept so were included in the good couple category. The distribution in the treatment groups was even.

The postoperative EF assessment revealed as expected lower SHIM scores in general as for each group apart. The lowest postoperative mean SHIM score was found in the patients of Tadalafil group $(9[8 ; 12]$ from 17 $[15 ; 20])$ compared to tadalafil + alprostadil group (11 [8; 13] from $18[17 ; 20])$. Regarding the postoperative ED status, we found that all patients had a degree of erectile dysfunction and many of them had severe, moderate, and mild-moderate ED with a relatively even distribution in all groups (Table II).
The post-prostatectomy ED is inflicted by neuropraxia secondary to intraoperative manipulation of the pudendal nerve bundles. Combined with local ischemia inflicted by the vascular ligation of iliac branches, the result is a hypoxic insult of the cavernosal cells that leads to fibrosis of the erectile tissue [21, 22].

Both tadalafil and alprostadil gel prescribed to our patients in the postoperative period has been long studied and demonstrated their efficacy for ED treatment, although the pathways of their action are different. Moncada et al. published a meta-analysis that concluded that the use of PDE5i and PGE1 combination in all forms of administration (intracavernosal injection, intraurethral gel, and topical application) is a better therapeutic mean for ED recovery than the separate use as single therapy [23].

Table II

General characteristics and patient's distribution according to treatment type

\begin{tabular}{|c|c|c|c|c|c|}
\hline \multicolumn{2}{|c|}{ Characteristics } & General distribution & $\begin{array}{c}\text { Tadalafil } \\
(n=56)\end{array}$ & $\begin{array}{c}\text { Tadalafil + alprostadil gel } \\
\qquad(\mathrm{n}=\mathbf{5 5})\end{array}$ & p value \\
\hline \multicolumn{2}{|l|}{ Age } & $66[63 ; 68.8]$ & $66[63.4 ; 69]$ & $65[62 ; 68]$ & 0.41 \\
\hline \multirow{8}{*}{ Comorbidities } & \multirow{8}{*}{$\begin{array}{l}\text { Hypertension } \\
\text { Diabetes mellitus } \\
\text { Atherosclerosis } \\
\text { Depressive disorder } \\
\text { Obesity } \\
\text { Smoking } \\
\text { Alcohol } \\
\text { Stroke }\end{array}$} & $74(66.7 \%)$ & $39(69.6 \%)$ & $35(63.6 \%)$ & 0.502 \\
\hline & & $28(25.2 \%)$ & $16(28.6 \%)$ & $12(21.8 \%)$ & 0.412 \\
\hline & & $48(43.2 \%)$ & $30(53.6 \%)$ & $18(32.7 \%)$ & 0.026 \\
\hline & & $8(7.2 \%)$ & $7(12.5 \%)$ & $1(1.8 \%)$ & 0.029 \\
\hline & & $39(35.1 \%)$ & $26(46.4 \%)$ & $13(23.6 \%)$ & 0.011 \\
\hline & & $45(40.5 \%)$ & $31(55.4 \%)$ & $14(25.5 \%)$ & 0.001 \\
\hline & & $34(30.6 \%)$ & $21(37.5 \%)$ & $13(23.6 \%)$ & 0.113 \\
\hline & & $19(17.1 \%)$ & $11(19.6 \%)$ & $8(14.5 \%)$ & 0.475 \\
\hline \multicolumn{2}{|c|}{ Preoperative PSA } & $11.7[8.3 ; 15.9]$ & $12.55[9.14 ; 17.72]$ & $9.8[7.62 ; 15.28]$ & 0.049 \\
\hline \multirow{3}{*}{ Stage } & $\mathrm{T} 2 \mathrm{a}$ & $15(13.5 \%)$ & $10(17.9 \%)$ & $5(9.1 \%)$ & \multirow[t]{3}{*}{0.37} \\
\hline & $\mathrm{T} 2 \mathrm{~b}$ & $31(27.9 \%)$ & $14(25 \%)$ & $17(30.9 \%)$ & \\
\hline & $\mathrm{T} 2 \mathrm{c}$ & $65(58.6 \%)$ & $32(57.1 \%)$ & $33(60 \%)$ & \\
\hline \multirow{4}{*}{ Gleason score } & Mean & $7[7 ; 8]$ & $7[7 ; 8]$ & $7[7 ; 8]$ & \multirow[t]{4}{*}{0.3} \\
\hline & 6 & $15(13.5 \%)$ & $10(17.9 \%)$ & $5(9.1 \%)$ & \\
\hline & 7 & $61(55 \%)$ & $31(55.4 \%)$ & $30(54.5 \%)$ & \\
\hline & 8 & $35(31.5 \%)$ & $15(26.8 \%)$ & $20(36.4 \%)$ & \\
\hline \multirow{3}{*}{$\begin{array}{l}\text { d'Amico risk } \\
\text { group }\end{array}$} & Low & $14(12.6 \%)$ & $9(16.1 \%)$ & $5(9.1 \%)$ & \multirow[t]{3}{*}{0.52} \\
\hline & Medium & $32(28.8 \%)$ & $15(26.8 \%)$ & $17(30.9 \%)$ & \\
\hline & Hygh & $65(58.6 \%)$ & $32(57.1 \%)$ & $33(60 \%)$ & \\
\hline \multirow{2}{*}{$\begin{array}{l}\text { Surgical } \\
\text { approach }\end{array}$} & RRP & $52(46.8 \%)$ & $31(55.4 \%)$ & $21(38.2 \%)$ & \multirow[t]{2}{*}{0.069} \\
\hline & LARP & $59(53.2 \%)$ & $25(44.6 \%)$ & $34(61.8 \%)$ & \\
\hline \multirow{3}{*}{$\begin{array}{l}\text { Nerve bundle } \\
\text { preservation } \\
\text { status }\end{array}$} & No NS & $31(27.9 \%)$ & $21(37.5 \%)$ & $10(18.2 \%)$ & \multirow[t]{3}{*}{0.026} \\
\hline & uniNS & $50(45 \%)$ & $25(44.6 \%)$ & $25(45.5 \%)$ & \\
\hline & biNS & $31(27.9 \%)$ & $10(17.9 \%)$ & $20(36.4 \%)$ & \\
\hline
\end{tabular}

Two reassessments were made after we have initiated the treatment regimen with tadalafil $5 \mathrm{mg}$ (QD) and Tadalafil $5 \mathrm{mg}$ (QD) + alprostadil (OD): first one at 3 months and the second one at 6 months (Table III). Results at 3 months were encouraging for patients in the tadalafil + alprostadil group which had a mean SHIM score of 16 points from 11 points found in the postop period compared to tadalafil group that had the same 9 points score as in postop assessment ( $\mathrm{p}<0.001$, Mann-Whitney U test). One patient in the combined therapy group had a normal erectile function after 3 months of treatment. We found that higher percentages of patients had mild and mild-moderate ED (34.54\%; $38.18 \%$ ) compared to the preoperative period (1.8\%; $40 \%$ ) and also the percentages of patients with severe ED fall from $14.55 \%$ to $7.28 \%$. At 6 months we found an improvement of the mean SHIM score for general distribution (13 points from 12 points at 3 months and 10 points in postop.), but in the separated treatment groups the results had some surprising changes. The mean SHIM score for the tadalafil group decreased to 8 pts at 6 months from 9 points at 3 months compared to the tadalafil + alprostadil group were the mean SHIM score remained stable at 16 points $(p<0.001$, 
FARMACIA, 2021, Vol. 69, 3

Mann-Whitney U test). While the percentages of mildmoderate and moderate ED patients decreased in tadalafil group compared to 3 months period (17.86\% vs. $25 \% ; 35.72 \%$ vs. $48.22 \%$ ), an increase of mild ED percentages was observed (12.5\% vs. $7.4 \%)$ but also an increase of severe ED percentage $(33.92 \%$ vs. $19.64 \%$ ) despite the PDE5i treatment.

Table III

Patients distribution according to surgery type and SHIM score

\begin{tabular}{|c|c|c|c|c|c|}
\hline \multicolumn{2}{|c|}{ Characteristics } & General distribution & $\begin{array}{c}\text { Tadalafil } \\
(\mathrm{n}=56)\end{array}$ & $\begin{array}{c}\text { Tadalafil + alprostadil gel } \\
\qquad(\mathbf{n}=\mathbf{5 5})\end{array}$ & p value \\
\hline \multicolumn{2}{|l|}{ Preop SHIM } & $18[16 ; 20]$ & $17[15 ; 20]$ & $18[17 ; 20]$ & 0.035 \\
\hline \multicolumn{2}{|l|}{ Good couple } & $92(82.9 \%)$ & $46(82.1 \%)$ & $46(83.6 \%)$ & 0.834 \\
\hline \multirow{5}{*}{ Preoperative ED status } & Absent & $10(9 \%)$ & $5(8.93 \%)$ & $5(9.09 \%)$ & \\
\hline & Mild & $62(55.9 \%)$ & $25(44.64 \%)$ & $37(67.27 \%)$ & \\
\hline & Mild-moderate & $36(32.4 \%)$ & $23(41.07 \%)$ & $13(23.64 \%)$ & \\
\hline & Moderate & $3(2.7 \%)$ & $3(5.36 \%)$ & 0 & \\
\hline & Severe & 0 & 0 & 0 & \\
\hline \multicolumn{2}{|l|}{ Postop SHIM } & $10[8 ; 13]$ & $9[8 ; 12]$ & $11[8 ; 13]$ & 0.161 \\
\hline \multirow{5}{*}{ Postoperative ED status } & Absent & $0(0 \%)$ & 0 & 0 & \\
\hline & Mild & $4(3.6 \%)$ & $3(5.35 \%)$ & $1(1.82 \%)$ & \\
\hline & Mild-moderate & $36(32.4 \%)$ & $14(25 \%)$ & $22(40)$ & \\
\hline & Moderate & $55(49.5 \%)$ & $31(55.36 \%)$ & $24(43.63 \%)$ & \\
\hline & Severe & $16(14.4 \%)$ & $8(14.29 \%)$ & $8(14.55 \%)$ & \\
\hline \multicolumn{2}{|l|}{3 Months SHIM } & $12[8 ; 16]$ & $9[8 ; 12.6]$ & $16[11.2 ; 18]$ & $<0.001$ \\
\hline \multirow{5}{*}{3 Months ED status } & Absent & $1(0.9 \%)$ & 0 & $1(1.82 \%)$ & \\
\hline & Mild & $23(20.7 \%)$ & $4(7.14 \%)$ & $19(34.54 \%)$ & \\
\hline & Mild-moderate & $35(31.5 \%)$ & $14(25 \%)$ & $21(38.18 \%)$ & \\
\hline & Moderate & $37(33.3 \%)$ & $27(48.22 \%)$ & $10(18.18 \%)$ & \\
\hline & Severe & $15(13.5 \%)$ & $11(19.64 \%)$ & $4(7.28 \%)$ & \\
\hline \multicolumn{2}{|l|}{6 Months SHIM } & $13[8 ; 17]$ & $8[7 ; 14]$ & $16[12 ; 19]$ & $<0.001$ \\
\hline \multirow{5}{*}{6 Months ED status } & Absent & $4(3.6 \%)$ & 0 & $4(7.27 \%)$ & \\
\hline & Mild & $30(27 \%)$ & $7(12.5 \%)$ & $23(41.82 \%)$ & \\
\hline & Mild-moderate & $26(23.4 \%)$ & $10(17.86 \%)$ & $16(29.1 \%)$ & \\
\hline & Moderate & $27(24.3 \%)$ & $20(35.72 \%)$ & $7(12.71 \%)$ & \\
\hline & Severe & $24(21.6 \%)$ & $19(33.92 \%)$ & $5(9.1 \%)$ & \\
\hline \multicolumn{2}{|c|}{ Preserved EF at 6 months } & $37(33.3 \%)$ & $6(10.7 \%)$ & $31(56.4 \%)$ & $<0.001$ \\
\hline
\end{tabular}

At the end of the 6 months observation period, we found that a total of 37 patients (33.3\% out of 111) have recovered the preoperative EF out of which 31 $(56.4 \%)$ were from tadalafil + alprostadil group while from tadalafil group only 6 patients $(10.7 \%)$ recovered the initial EF ( $p<0.001$, Mann-Whitney U test).

The results gathered after 6 months were processed in a multivariable analysis in which we also included other variables that are demonstrated to have an impact over EF like associated illnesses, stage and risk group of PCa at operation time, preoperative EF, type of surgical approach and nerve bundle preservation. Thus, we could observe that the patients selected for the tadalafil + alprostadil group had less comorbidities, had an overall lower PCa risk score, and were likely operated laparoscopic than open compared to the patients from tadalafil group. Also, the nerve bundle preservation (uni- or bi-lateral) was more likely to be performed to tadalafil + alprostadil group than the other. Thus, in the multivariable analysis, we found that the combined administration of tadalafil $5 \mathrm{mg}$ QD and alprostadil gel OD after prostatectomy increases almost 10 times the chance of EF recovery to the initial preoperative score (OR: 3.55; 95\% CI: 1,465 - 8.63) (Figure 1).

Regarding the postoperative ED status, we found that all patients had a degree of erectile dysfunction and many of them had severe, moderate, and mildmoderate ED with a relatively even distribution in all groups. We also observed that postoperatory SHIM was better in patients who underwent laparoscopic surgery.

In this regard, we can affirm that the association of tadalafil $5 \mathrm{mg}$ QD and alprostadil gel OD can increase the chance of EF recovery after radical prostatectomy 10 folds. This outcome can be influenced by other factors like surgical technique of preservation, atherosclerosis, depression, obesity, tobacco use. In order to reduce the risk of altering the results we used a multivariable regression model in which we used those factors alongside the surgical technique (laparoscopic $v s$. open) so we can analyse properly the patients' selection bias. 


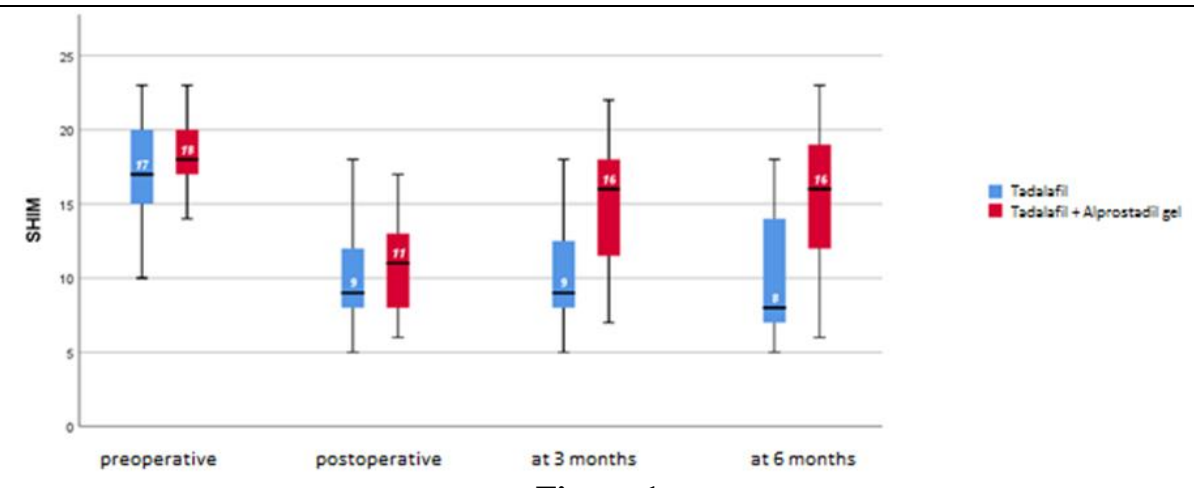

Figure 1.

SHIM score evolution according to ED treatment

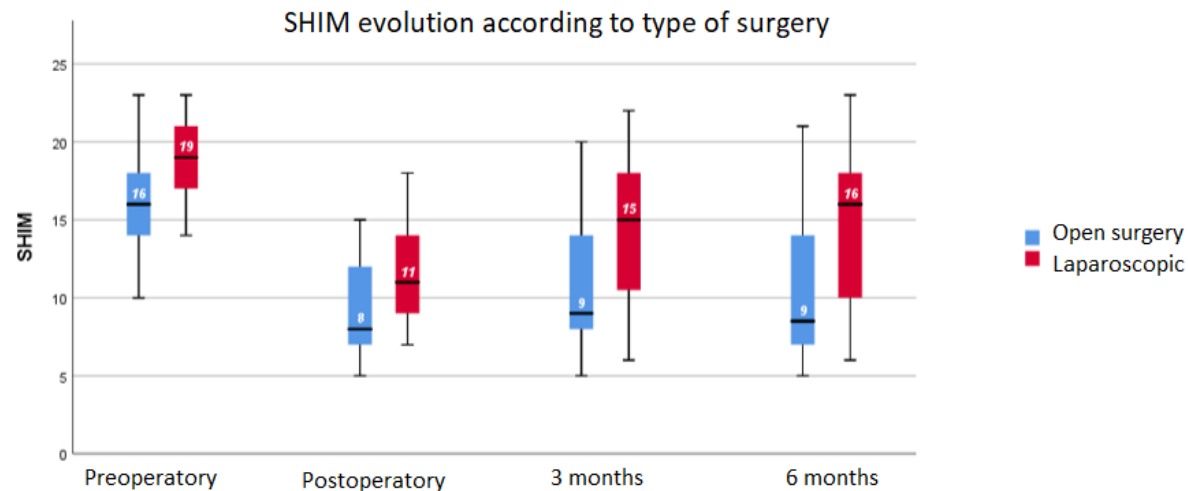

Figure 2.

SHIM score evolution according to the type of surgery

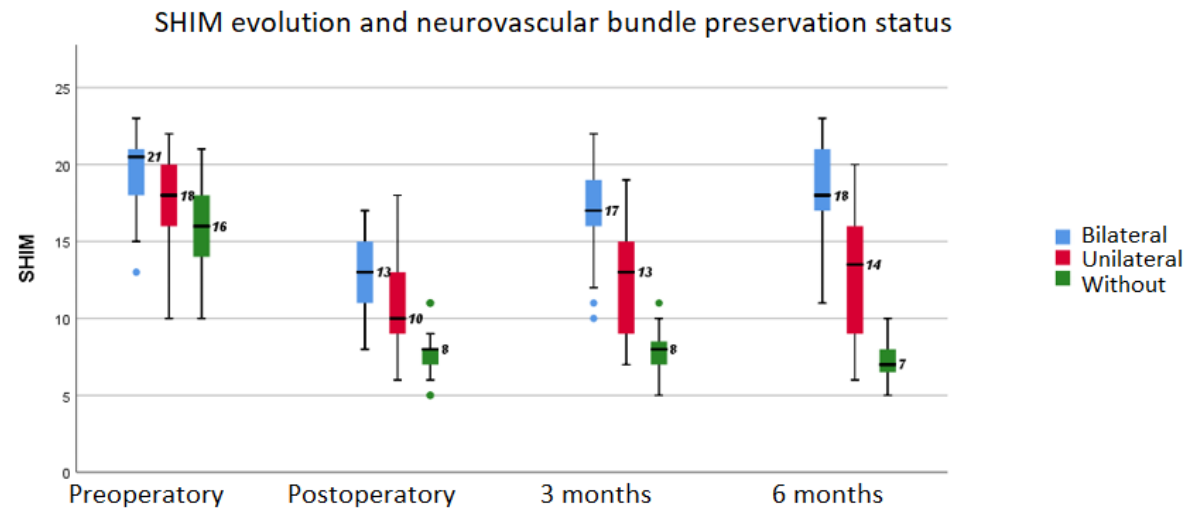

Figure 3 .

SHIM score evolution and neurovascular preservation status

Taking into consideration the physiological relationship between nerve sparing surgical technique and its impact on ED, the results seem to be logical. (OR 3.23, 95\% CI: 1.82 - 5.737) - unilateral or bilateral nerve sparing increase erectile function recovery for 3.23 times.

Tadalfil $5 \mathrm{mg}$ combined with Alprostadil gel intraurethral on demand increases penile rehabilitabion after radical prostatectomy with an OR of 3.55, $95 \%$ CI: 1.465 8.63 with statistical significance.

\section{Conclusions}

In this long-term study we have reached the main objective of proving the efficacy and safety of
PDE5i and PGE1 combined therapy compared to PDE5i mono therapy for the treatment of postoperative ED. In the multivariable analysis of NS procedure, it was found that the patients from tadalafil + alprostadil group had a statistically significant EF improvement compared to the tadalafil QD group $(\mathrm{p}=0.026)$.

\section{Conflict of interest}

The authors declare no conflict of interest.

\section{References}

1. Rawla P, Epidemiology of Prostate Cancer. World J Oncol., 2019; 10(2): 63-89. 
2. Mottet N, van den Bergh RCN, Briers E, Van den Broeck T, Cumberbatch MG, De Santis M, Fanti S, Fossati N, Gandaglia G, Gillessen S, Grivas N, Grummet J, Henry AM, van der Kwast TH, Lam TB, Lardas M, Liew M, Mason MD, Moris L, Oprea-Lager DE, van der Poel HG, Rouvière O, Schoots IG, Tilki D, Wiegel T, Willemse PM, Cornford P, EAU-EANMESTRO-ESUR-SIOG Guidelines on Prostate Cancer2020 Update. Part 1: Screening, Diagnosis, and Local Treatment with Curative Intent. Eur Urol., 2021; 79(2): 243-262.

3. Kim JH, Lee SW, Current status of penile rehabilitation after radical prostatectomy. Korean J Urol., 2015; 56(2): 99-108.

4. Park YH, Jeong CW, Lee SE, A comprehensive review of neuroanatomy of the prostate. Prostate Int., 2013; 1(4): 1-7.

5. Spataru RI, Iozsa DA, Ivanov M, Preputial calculus in a neurologically-impaired child. Indian Pediatrics, 2015; 52: 149-150.

6. Blecher G, Almekaty K, Kalejaiye O, Minhas S, Does penile rehabilitation have a role in the treatment of erectile dysfunction following radical prostatectomy? F1000Res., 2017; 6: 1923: 1-12.

7. Philippou YA, Jung JH, Steggall MJ, O'Driscoll ST, Bakker CJ, Bodie JA, Dahm P, Penile rehabilitation for postprostatectomy erectile dysfunction. Cochrane Database Syst Rev., 2018; 10(10): CD012414.

8. Chauhan S, Coelho RF, Rocco B, Palmer KJ, Orvieto MA, Patel VR, Techniques of nerve-sparing and potency outcomes following robot-assisted laparoscopic prostatectomy. Int Braz J Urol., 2010; 36(3): 259-272.

9. Pricop C, Furtunescu LF, Rădăvoi D, Jinga V, Cumpănaş A, Anton-Păduraru DT, Miron A, Toma C, Puia D, Antibiotic prophylaxis in transurethral resections: what are the criteria that should be followed? Farmacia, 2020; 68(6): 1021-1028.

10. Cappelleri JC, Rosen RC, The Sexual Health Inventory for Men (SHIM): A 5-year review of research and clinical experience. Int J Impot Res., 2005; 17(4): 307-319.

11. Chen L, Shi GR, Huang DD, Li Y, Ma CC, Shi M, Su BX, Shi GJ. Male sexual dysfunction: A review of literature on its pathological mechanisms, potential risk factors, and herbal drug intervention. Biomed Pharmacother., 2019; 112: 108585: 1-13.
12. Vlachopoulos C, Jackson G, Stefanadis C, Montorsi P, Erectile dysfunction in the cardiovascular patient. Eur Heart J., 2013; 34(27): 2034-2046.

13. Nicolai MP, Liem SS, Both S, Pelger RC, Putter H, Schalij MJ, Elzevier HW, A review of the positive and negative effects of cardiovascular drugs on sexual function: A proposed table for use in clinical practice. Netherlands Hear J., 2014; 22(1): 11-19.

14. Terzic B, Markovic S, Grujic J, Djukic L, Cardiovascular drugs and erectile dysfunction. Hosp Pharmacol Int Multidiscip J., 2014; 1(3): 174-179.

15. Maiorino MI, Bellastella G, Esposito K, Diabetes and sexual dysfunction: current perspectives. Diabetes Metab Syndr Obes., 2014; 7: 95-105.

16. Moon KH, Park SY, Kim YW, Obesity and Erectile Dysfunction: From Bench to Clinical Implication. World J Mens Health., 2019; 37(2): 138-147.

17. Liu Q, Zhang Y, Wang J, Li S, Cheng Y, Guo J, Tang Y, Zeng H, Zhu Z. Erectile Dysfunction and Depression: A Systematic Review and Meta-Analysis. J Sex Med., 2018; 15(8): 1073-1082.

18. Tostes RC, Carneiro FS, Lee AJ, Giachini FR, Leite $\mathrm{R}$, Osawa Y, Webb RC, Cigarette smoking and erectile dysfunction: focus on NO bioavailability and ROS generation. J Sex Med., 2008; 5(6): 1284-1295.

19. Dehelean L, Romosan AM, Andor M, Buda VO, Bredicean AC, Manea MM, Papava I, Romosan RS, Clinical factors influencing antipsychotic choice, dose and augmentation in patients treated with long acting antipsychotics. Farmacia, 2020; 68(1): 35-41.

20. Wang XM, Bai YJ, Yang YB, Li JH, Tang Y, Han $\mathrm{P}$, Alcohol intake and risk of erectile dysfunction: a dose-response meta-analysis of observational studies. Int J Impot Res., 2018; 30(6): 342-351.

21. Clavell-Hernandez J, Ermeç B, Kadioğlu A, Wang $\mathrm{R}$, Perplexity of penile rehabilitation following radical prostatectomy. Turkish J Urol., 2019; 45(2): 77-82.

22. Ko YH, Functional recovery after radical prostatectomy for prostate cancer. Yeungnam Univ J Med., 2018; 35(2): 141-149.

23. Moncada I, Martinez-Salamanca J, Ruiz-Castañe E, Romero J, Combination therapy for erectile dysfunction involving a PDE5 inhibitor and alprostadil. Int $J$ Impot Res., 2018; 30(5): 203-208. 